\title{
Analisa Klasifikasi C4.5 Terhadap Faktor Penyebab Menurunnya Prestasi Belajar Mahasiswa Pada Masa Pandemi
}

\author{
Khairunnissa Fanny Irnanda ${ }^{1, *}$, Dedy Hartama ${ }^{2}$, Agus Perdana Windarto ${ }^{3}$ \\ Sistem Informasi, STIKOM Tunas Bangsa, Pematangsiantar, Medan-Indonesia \\ Email: 1,*nissafanny@gmail.com, ${ }^{2}$ dedyhartama@amiktunasbangsa.ac.id, ${ }^{3}$ agus.perdana@ amiktunasbangsa.ac.id \\ Email Penulis Korespondensi: nissafanny@gmail.com
}

\begin{abstract}
Abstrak-Tujuan dari penelitian adalah untuk mengklasifikasi faktor penyebab menurunnya prestasi belajar mahasiswa pada masa pandemi dengan menggunakan metode datamining C4.5. Sumber data penelitian diperoleh dengan melakukan wawancara dan pembagian angket terhadap mahasiswa semester 7 tahun ajaran 2020-2021 program studi sistem informasi. Atribut yang digunakan pada klasifikasi sistem pembelajaran mahasiswa antara lain: Cara Belajar (C1), Waktu Belajar (C2), Pemahaman Materi (C3), Pemberian Tugas (C4) dan Lingkungan (C5). Hasil perhitungan menyebutkan atribut Pemahaman Materi(C3) adalah atribut yang paling berpengaruh terhadap menurunnya prestasi belajar mahasiswa. Pengujian juga dilakukan dengan menggunakan bantuan software Rapidminer dan diperoleh akurasi 97,5\%.
\end{abstract}

Kata Kunci: Klasifikasi; Datamining; C4.5; Prestasi Belajar; Pandemi

Abstract-The purpose of the study was to classify the factors causing the decline in student achievement during the pandemic using the C4.5 datamining method. Sources of research data were obtained by conducting interviews and distributing questionnaires to 7th semester students of the 2020-2021 school year information system study program. Attributes that used in the classification of the factors causing the decline in student achievement include: Learning Method (C1), Study Time (C2), Material Understanding (C3), Giving Assignments (C4) and Environment (C5). The results of the calculation show that the Material Understanding (C3) attribute is the attribute that most influences the decline in student learning achievement. Testing was also carried out using the help of Rapidminer software and obtained an accuracy of $97.5 \%$.

Keywords: Classification; Datamining; C4.5; Learning Achievement; Pandemic

\section{PENDAHULUAN}

Pada akhir tahun 2019 kita diguncangkan oleh suatu wabah yaitu virus covid-19atau disebut juga dengan virus corona. Virus iniberasal dari pasar didaerah wuhan china, dalamselang beberapa minggu saja virus ini sangatcepat menyebar keseluruh penjuru kota china dan semakin lama menyebar keseluruh dunia termasuk juga di Indonesia [1]. Maka dari itu pemerintah mengambil keputusan untuk tidak melakukan apapun kegiatan diluar rumah. Kementrian pedidikan menerapkan kebijakan dengan belajar dirumah saja dimana belajar dirumah saja ini dengan menggunakan sistem online atau daring [2]. Sistem pembelajaran online ini memanfaatkan aplikasi whatsapp dan mengunakan beberapa aplikasi pembelajaran seperti google classroom,zoom, google meet,discord dan lain-lain. Dimana aplikasi ini dapat mempermudah guru atau dosen dapat melangsungkan ajar-mengajar kepada siswa-siswanya walaupun tidak bertatap muka secara langsung dan juga dapat memeberikan tugas secara online. Pengajar dituntut untuk memberikan pembelajaran yang baik, menciptakan suasana yang kondusif untuk belajar secara kreatif dan inovatif menggunakan media belajar yang menarik agar siswa maupun mahasiswa dapat memahami materi pembelajaran dan tujuan pembelajaran dapat tercapai.

Pada saat menggunakan sistem belajar online ini tidak selamanya berjalan dengan lancar pasti ada saja kendala-kendala yang dapat terjadi contohnya beberapa materi yang disampaikan kurang jelas dan mahasiswa juga kurang memahami apa yang sampaikan pengajar, banyak dari keluarga siswa yang hanya memilki android tidak lebih dari satu buah, bahkan beberapa keluarga belum memiliki gawai sejenis ini dan cukup merepotkan jika harus di timpakan terhadap sarana daring itu sendiri, kurangnya kedisiplinan mahasiswa dalam mengumpulkan tugasnya dan lain sebagainya.

Adanya kendala dalam proses pembelajaran menyebabkan terjadinya beberapa perubahan terhadap peserta didik yang pada akhirnya berpengaruh terhadap menurunnya motivasi dan prestasi belajarnya [3]. Motivasi dan prestasi belajar merupakan dua aspek yang saling mempengaruhi.prestasi belajar akan menjadi lebih optimal jika di dalamnya terkandung nilai motivasi yang tinggi, itulah kenapa jika seorang siswa berkurang motivasinya, maka prestasi belajarnya pun juga ikut terdampak [4]. Demi menumbuhkan tingkat motivasi belajar yang lebih baik, maka diperlukan suatu kiat khusus untuk mengubah perilaku siswa, untuk itu peneliti menggunakan teknik data mining klasifikasi [5]-[11]untuk menyelesaikan permasalah menurunnya prestasi belajar mahasiswa.

Teknik datamining yang digunakana adalah algoritma klasifikasi C4.5. Penggunaan klasifikasi C4.5 berupa bentuk tingkatan yang berbeda mulai dari akar ke daun secara hirarki. Proses ini berlanjuthingga mencapai node yang tidak dapat dibagi lagi. Beberapa penelitian terdahulu menggunakan metode $\mathrm{C} 4.5$ sebagai solusi dari permasalah yang diangkat seperti yang dilakukan dengan judul penelitian "Penerapan Klasifikasi C4.5 Dalam Meningkatkan Kecakapan Bahasa Inggris dalam Masyarakat". Pada penelitian inidijelaskan bahwa algoritma $\mathrm{C} 4.5$ dapat diterapkan pada meningkatkan kecakapan berbahasa inggris dalam masyarakat dengan lima 
kategori antara lain: membaca, praktek, pelafalan, lingkungan dan pemanfaatan teknologi. Hasilpenelitian menyebutkan bahwa atribut yang paling berpengaruh adalah praktek dengan presentase $95 \%$.

Berdasarkan alasan tersebut peneliti menggunakan metode C4.5 untuk menganalisa faktor penyebab menurunnya prestasi belajar mahasiswa yang bertujuan untuk melihat atribut yang paling berpengaruh pada menurunnya prestasi belajar mahasiswa. Dimana hasil dari penelitian dapat menjadi masukan kepada mahasiswa/i agar dapat meningkatkan semangat belajar dan motivasi belajarnya di masa pandemi ini dan tetap mengikuti protokol kesehatan.

\section{METODOLOGI PENELITIAN}

\subsection{Data Mining}

Data mining adalah suatu istilah yang digunakan untuk menguraikan penemuan pengetahuan di dalam database [12]. Data mining adalah proses yang menggunakan teknik statistic, matematika, kecerdasan buatan, dan machine learning untuk mengekstraksi dan mengident ifikasi informasi yang bermanfaat dan pengetahuan yang terkait dari berbagai database besar. Data mining, sering juga disebut sebagai Knowledge Discovery in Database (KDD) [6], [13]. KDD adalah kegiatan yang meliputi pengumpulan,pemakaian data, historis untuk menemukan keteraturan,pola atau hubungan dalam set data berukuran besar [14].

Data yang diolah kemudian menghasilkan suatu pengetahuan baru yang bersumber dari data lama, hasil dari pengolahan data tersebut dapat digunakan dalam menentukan keputusan di masa depan. Data mining memiliki beberapa fungsi yaitu:

a) Fungsi deskripsi (Description)

b) Fungsi estimasi (Estimation)

c) Fungsi prediksi (Prediction)

d) Fungsi klasifikasi (Classification)

e) Fungsi pengelompokan (Classsification)

f) Fungsi assosiasi (Association)

\subsection{Algoritma C4.5}

Algoritma C4.5 adalah salah satu metode untuk membuat decision tree berdasarkan training data yang telah disediakan. Algoritma C4.5 merupakan pengembangan dari ID3 [5]. Sedang pohon keputusan dapat diartikan suatu cara untuk memprediksi atau mengklarifikasi yang sangat kuat. Pohon keputusan dapat membagi kumpulan data yang besar menjadi himpunan-himpunan record yang lebih kecil dengan menerapkan serangkaian aturan keputusan [15].

Secara umum algoritmaC4.5untuk membangun pohon keputusan adalah sebagai berikut [16], [17]:

1) Pilih atribut sebagai akar

2) Buat cabang untuk masing-masing nilai

3) Bagi kasus dalam cabang

4) Ulangi proses untuk masing-masing cabang sampai semua kasus pada cabang memiliki kelas yang sama.

Rumus Algoritma C4.5 terbagi menjadi 2 rumus, Untuk menghitung gain digunakan rumus seperti tertera dalam persamaan 1 berikut:

$$
\operatorname{Gaint}(S, A)=\operatorname{Entrophy}(S)-\sum_{i=1}^{n} \frac{\left|S_{1}\right|}{|S|} * \operatorname{Entropy}\left(S_{i}\right)
$$

Keterangan:

S : Himpunan kasus

A : Atribut

n : Jumlah partisi atribut A

|Si $\quad$ : Jumlah kasus pada partisi ke-i

$|\mathrm{S}| \quad$ : Jumlah kasus dalam $\mathrm{S}$

Sementara itu, penghitungan nilai entropi dapat dilihat pada persamaan 2 berikut :

$$
\operatorname{Entrophy}(S)=\sum_{i=1}^{n}-p i * \log _{2} p i
$$

\subsection{Rapidminner}

RapidMiner merupakan software/perangkat lunak untuk pengolahan data. Dengan menggunakan prinsip dan algoritma data mining, RapidMiner mengekstrak pola-pola dari data set yang besar dengan mengkombinasikan metode statistika, kecerdasan buatan dan database [18]. RapidMiner adalah sebuah lingkungan machine learning datamining, text mining dan predictive analytics[19]. RapidMiner memiliki kurang lebih 500 operator data mining, termasuk operator untuk input, output, data preprocessing dan visualisasi. RapidMiner merupakan software yang berdiri sendiri untuk analisis data dan sebagai mesin data mining yang dapat diitegrasikan pada 
produknya sendiri. RapidMiner ditulis dengan menggunakan bahasa java sehingga dapat bekerja di semua sistem operasi.

\section{HASIL DAN PEMBAHASAN}

Penelitian ini dilakukan di STIKOM Tunas Bangsa dengan lokasi penelitian di Kota Pematangsiantar. Data diperoleh dengan cara wawancara dan memberikan angket secara random kepada Mahasiswa semester 7 . Selanjutnya data dimasukan atau diolah menggunakan Microsoft Office Excel, maka dilakukan pengolahan data kuisioner, dengan cara mengambil nilai rata-rata Cara Belajar (C1), Waktu Belajar (C2), Pemahaman Materi (C3), Pemberian Tugas (C4) dan Lingkungan (C5), hasil (Nilai Indeks Prestasi Kumulatif). Adapun hasil preprocessing data akumulasi yang didapat adalah sebagai berikut:

Tabel 1. Hasil preprocessing data akumulasi

\begin{tabular}{|c|c|c|c|c|c|}
\hline Cara Belajar (C1) & Waktu Belajar (C2) & $\begin{array}{l}\text { Pemahaman } \\
\text { Materi (C3) }\end{array}$ & $\begin{array}{c}\text { Pemberian } \\
\text { Tugas } \\
\text { (C4) }\end{array}$ & $\begin{array}{l}\text { Lingkungan } \\
\text { (C5) }\end{array}$ & Hasil IPK \\
\hline Memiliki Media & Sebentar & Tidak paham & Jarang & Tidak Kondusif & Menurun \\
\hline Memiliki Media & Lama & paham & Sering & Kondusif & Meningkat \\
\hline Memiliki Media & Sebentar & paham & Sering & Kondusif & Meningkat \\
\hline Tidak Memiliki Media & Sebentar & Tidak paham & Sering & Kondusif & Meningkat \\
\hline Memiliki Media & Lama & paham & Sering & Kondusif & Meningkat \\
\hline Memiliki Media & Sebentar & Tidak paham & Jarang & Tidak Kondusif & Menurun \\
\hline Memiliki Media & Tidak Belajar & Tidak paham & Sering & Tidak Kondusif & Menurun \\
\hline Memiliki Media & Sebentar & paham & Jarang & Kondusif & Meningkat \\
\hline Memiliki Media & Tidak Belajar & Tidak paham & Jarang & Tidak Kondusif & Menurun \\
\hline Memiliki Media & Lama & paham & Sering & Kondusif & Meningkat \\
\hline Memiliki Media & Tidak Belajar & Tidak paham & Jarang & Tidak Kondusif & Menurun \\
\hline Memiliki Media & Sebentar & Tidak paham & Sering & Tidak Kondusif & Menurun \\
\hline Memiliki Media & Sebentar & paham & Sering & Kondusif & Meningkat \\
\hline Memiliki Media & Lama & paham & Sering & Kondusif & Meningkat \\
\hline Memiliki Media & Tidak Belajar & Tidak paham & Jarang & Tidak Kondusif & Menurun \\
\hline Tidak Memiliki Media & Sebentar & paham & Jarang & Tidak Kondusif & Menurun \\
\hline Memiliki Media & Tidak Belajar & Tidak paham & Sering & Tidak Kondusif & Menurun \\
\hline Memiliki Media & Tidak Belajar & Tidak paham & Sering & Tidak Kondusif & Menurun \\
\hline Memiliki Media & Sebentar & paham & Sering & Kondusif & Meningkat \\
\hline Memiliki Media & Sebentar & paham & Sering & Kondusif & Meningkat \\
\hline Memiliki Media & Lama & paham & Sering & Kondusif & Meningkat \\
\hline Memiliki Media & Tidak Belajar & Tidak paham & Sering & Tidak Kondusif & Menurun \\
\hline Memiliki Media & Sebentar & Tidak paham & Sering & Kondusif & Menurun \\
\hline Tidak Memiliki Media & Sebentar & Tidak paham & Jarang & Tidak Kondusif & Menurun \\
\hline Tidak Memiliki Media & Tidak Belajar & Tidak paham & Sering & Tidak Kondusif & Menurun \\
\hline Memiliki Media & Tidak Belajar & Tidak paham & Sering & Tidak Kondusif & Menurun \\
\hline Memiliki Media & Tidak Belajar & Tidak paham & Sering & Kondusif & Menurun \\
\hline Memiliki Media & Sebentar & paham & Sering & Kondusif & Meningkat \\
\hline Memiliki Media & Lama & paham & Jarang & Kondusif & Meningkat \\
\hline Memiliki Media & Tidak Belajar & Tidak paham & Jarang & Tidak Kondusif & Menurun \\
\hline Memiliki Media & Tidak Belajar & Tidak paham & Sering & Tidak Kondusif & Menurun \\
\hline Memiliki Media & Sebentar & paham & Jarang & Kondusif & Meningkat \\
\hline Memiliki Media & Sebentar & paham & Sering & Kondusif & Meningkat \\
\hline Memiliki Media & Tidak Belajar & Tidak paham & Jarang & Tidak Kondusif & Menurun \\
\hline Memiliki Media & Lama & paham & Sering & Kondusif & Meningkat \\
\hline Memiliki Media & Tidak Belajar & Tidak paham & Sering & Tidak Kondusif & Menurun \\
\hline Tidak Memiliki Media & Sebentar & paham & Jarang & Tidak Kondusif & Meningkat \\
\hline Memiliki Media & Sebentar & Tidak paham & Sering & Tidak Kondusif & Menurun \\
\hline Memiliki Media & Lama & paham & Sering & Kondusif & Meningkat \\
\hline Memiliki Media & Tidak Belajar & Tidak paham & Jarang & Tidak Kondusif & Menurun \\
\hline
\end{tabular}

Hasil preprocessing yang didapat kemudian diolah ke dalam Decisiontree menggunakan software Rapidminer untuk mengetahui klasifikasi peningkatan sistem pembelajaran mahasiswa, adapun gambar pohon keputusan sebagai berikut: 
ISSN 2614-5278 (media cetak), ISSN 2548-8368 (media online)

Available Online at https://ejurnal.stmik-budidarma.ac.id/index.php/mib DOI 10.30865/mib.v5i1.2763

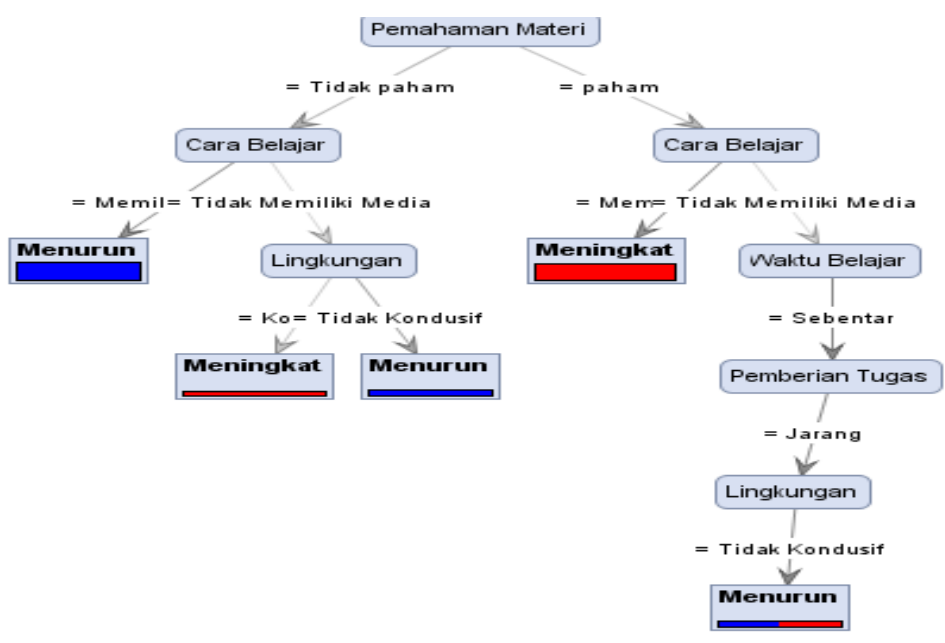

Gambar 1. Pohon Keputusan Peningkatan Sistem Pembelajaran

Jika dilihat berdasarkan hasil pohon keputusan(decissionTree) klasifikasi faktor penyebab menurunnya prestasi belajar mahasiswa pada masa pandemi, bahwa atribut yang mempunyai pengaruh utama mendapatkan predikat keberhasilan adalah variabel C3 (Pemahaman Materi) yang menempati sebagai simpul akar seperti yang ditampilkan pada gambar berikut:

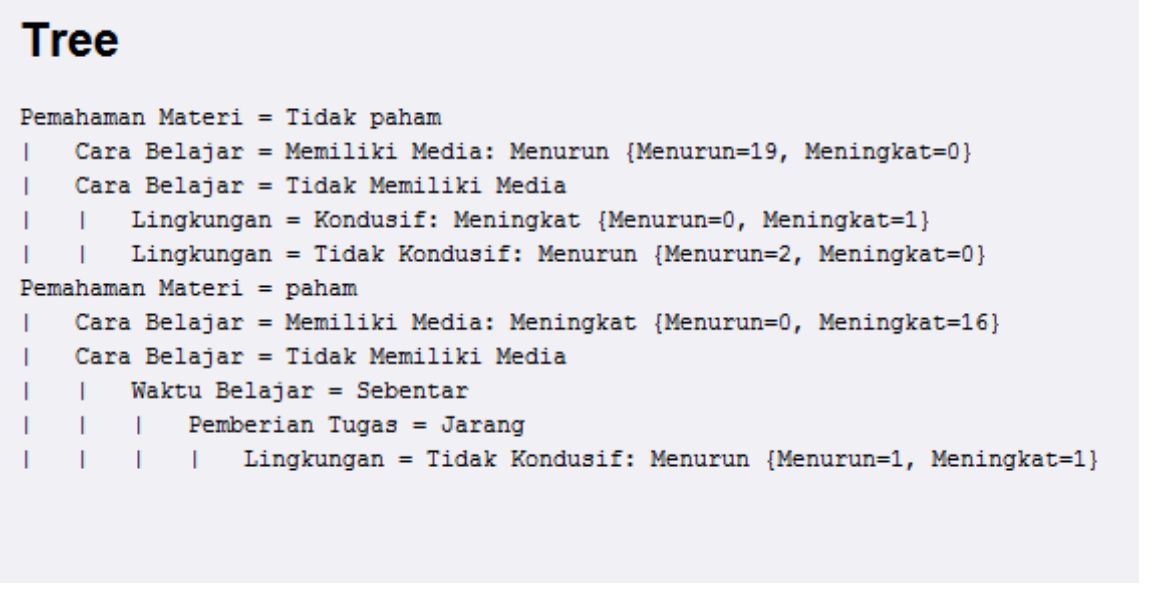

Gambar 2. Hasil Pohon Keputusan Faktor Menurunnya Prestasi Belajar Berupa Teks

Berdasarkan gambar 2, peneliti melakukan data testing dengan menggunakan software Rapidminer untuk melihat kesesuaian metode yang digunakan dengan kasus yang sedang diteliti. Berdasarkan hasil perhitungan diperoleh akurasi sebesar 97.5\%. Hal ini menjelaskan bahwa metode C4.5 dapat diterapkan sebagai factor yang paling berpengaruh pada menurunnya prestasi belajar mahasiswa. Berikut hasil perhitungan dengan menggunakan software Rapidminer.

\begin{tabular}{|c|c|c|c|}
\hline & true Menurun & true Meningkat & class precision \\
\hline pred. Menurun & 22 & 1 & $95.65 \%$ \\
\hline pred. Meningkat & 0 & 17 & $100.00 \%$ \\
\hline class recall & $100.00 \%$ & $94.44 \%$ & \\
\hline
\end{tabular}

Gambar 3. Akurasi dengan menggunakan software Rapidminer

\section{KESIMPULAN}

Berdasarkan hasil penelitian yang dilakukan dapat disimpulkan bahwa penerapan klasifikasi C4.5 pada faktor penyebab menurunnya prestasi belajar mahasiswa di masa pandemi dapat diterapkan. Atribut yang digunakan sebagai parameter peningkatan sistem pembelajaran mahasiswa antara lain: Cara Belajar (C1), Waktu Belajar (C2), Pemahaman Materi (C3), Pemberian Tugas (C4) dan Lingkungan (C5). Hasil perhitungan menyebutkan atribut C3 (Pemahaman Materi) merupakan variabel yang paling berpengaruh terhadap menurunnya prestasi 
JURNAL MEDIA INFORMATIKA BUDIDARMA

Volume 5, Nomor 1, Januari 2021, Page 327-331

ISSN 2614-5278 (media cetak), ISSN 2548-8368 (media online)

Available Online at https://ejurnal.stmik-budidarma.ac.id/index.php/mib

DOI 10.30865/mib.v5i1.2763

belajar mahasiswa di masa pandemi. Pengujian juga dilakukan untuk membuktikan apakah metode C4.5 dapat diterapkan pada kasus penyebab menurunnya prestasi belajar mahasiswa di masa pandemi dengan menggunakan bantuan software Rapidminer dan diperoleh akurasi $97.5 \%$.

\section{REFERENCES}

[1] F. Suasty and A. A. Hadi, "Penggunan Media Pembelajaran Video untuk Solusi Penurunan Pemahaman Materi Pembelajaran Ketika Belajar Online Akibat Pandemic Covid-19," vol. 1, no. 1, pp. 12-16, 2020.

[2] B. Nadeak, C. P. Juwita, and E. Sormin, "Hubungan kemampuan berpikir kritis mahasiswa dengan penggunaan media sosial terhadap capaian pembelajaran pada masa pandemi Covid-19," vol. 8, no. 2, pp. 98-104, 2020.

[3] A. Cahyani et al., "Motivasi Belajar Siswa SMA pada Pembelajaran Daring di Masa Pandemi Covid-19," vol. 3, no. 01, pp. 123-140, 2020 .

[4] M. Belajar, S. Pada, M. Pandemi, C. Di, and K. V. S. D. N. Ngembel, "The Effectiveness Of Bion ( Bintang Online ) In Improving The Learning Motivation Of 5 Th Grade Students In State Elementary School 1 Of Ngembel,” vol. 6, pp. 184-198, 2020.

[5] A. P. Windarto, U. Indriani, M. R. Raharjo, and L. S. Dewi, "Bagian 1: Kombinasi Metode Klastering dan Klasifikasi (Kasus Pandemi Covid-19 di Indonesia),” J. Media Inform. Budidarma, vol. 4, no. 3, p. 855, 2020, doi: 10.30865/mib.v4i3.2312.

[6] B. Supriyadi, A. P. Windarto, T. Soemartono, and Mungad, "Classification of natural disaster prone areas in Indonesia using Kmeans," Int. J. Grid Distrib. Comput., vol. 11, no. 8, pp. 87-98, 2018, doi: 10.14257/ijgdc.2018.11.8.08.

[7] A. Waluyo, H. Jatnika, M. R. S. Permatasari, T. Tuslaela, I. Purnamasari, and A. P. Windarto, "Data Mining Optimization uses C4.5 Classification and Particle Swarm Optimization (PSO) in the location selection of Student Boardinghouses," IOP Conf. Ser. Mater. Sci. Eng., vol. 874, no. 1, pp. 1-9, 2020, doi: 10.1088/1757-899X/874/1/012024.

[8] M. Widyastuti, A. G. Fepdiani Simanjuntak, D. Hartama, A. P. Windarto, and A. Wanto, "Classification Model C.45 on Determining the Quality of Custumer Service in Bank BTN Pematangsiantar Branch,” J. Phys. Conf. Ser., vol. 1255, no. 1, pp. 1-6, 2019, doi: $10.1088 / 1742-6596 / 1255 / 1 / 012002$.

[9] S. Sundari, Karmila, M. N. Fadli, D. Hartama, A. P. Windarto, and A. Wanto, "Decision Support System on Selection of Lecturer Research Grant Proposals using Preferences Selection Index,” J. Phys. Conf. Ser., vol. 1255, no. 1, pp. 1-8, 2019, doi: 10.1088/17426596/1255/1/012006.

[10] W. Katrina, H. J. Damanik, F. Parhusip, D. Hartama, A. P. Windarto, and A. Wanto, "C.45 Classification Rules Model for Determining Students Level of Understanding of the Subject,” J. Phys. Conf. Ser., vol. 1255, no. 1, 2019, doi: 10.1088/17426596/1255/1/012005.

[11] A. P. Windarto, J. Na, and A. Wanto, "Bagian 2: Model Arsitektur Neural Network dengan Kombinasi K- Medoids dan Backpropagation pada kasus Pandemi COVID-19 di Indonesia,” vol. 4, pp. 1175-1180, 2020, doi: 10.30865/mib.v4i4.2505.

[12] K. F. Irnanda and A. P. Windarto, "Penerapan Klasifikasi C4 . 5 Dalam Meningkatkan Kecakapan Berbahasa Inggris dalam Masyarakat," pp. 304-308, 2020

[13] F. Rahman, I. I. Ridho, M. Muflih, S. Pratama, M. R. Raharjo, and A. P. Windarto, "Application of Data Mining Technique using KMedoids in the case of Export of Crude Petroleum Materials to the Destination Country," IOP Conf. Ser. Mater. Sci. Eng., vol. 835, no. 1, 2020, doi: 10.1088/1757-899X/835/1/012058.

[14] M. Ridwan, H. Suyono, and M. Sarosa, "Penerapan Data Mining Untuk Evaluasi Kinerja Akademik Mahasiswa Menggunakan Algoritma Naive Bayes Classifier,” vol. 7, no. 1, pp. 59-64, 2013

[15] S. Sivakumari, R. P. Priyadarsini, and P. Amudha, "Accuracy Evaluation Of C4.5 And Naive Bayes Classifier Using Attribute Ranking Method,” Int. J. Comput. Intell. Syst., vol. 2, no. 1, pp. 60-68, 2009.

[16] E. Indra, K. Ho, Arlinanda, R. Hakim, D. Sitanggang, and O. Sihombing, “Application of C4.5 Algorithm for Cattle Disease Classification," J. Phys. Conf. Ser., vol. 1230, no. 1, 2019, doi: 10.1088/1742-6596/1230/1/012070.

[17] Hermanto, S. J. Kuryanti, and S. N. Khasanah, "Comparison of Naïve Bayes Algorithm , C4 . 5 and Random Forest for Service Classification Ojek Online," J. Publ. Informatics Eng. Res., vol. 3, no. April 2019, pp. 266-274, 2019.

[18] B. R. C. T. I et al., "Implemetasi k-means clustering pada rapidminer untuk analisis daerah rawan kecelakaan,” no. April, pp. 58-62, 2017.

[19] A. P. Windarto, P. Studi, S. Informasi, and D. Mining, "Penerapan Data Mining Pada Ekspor Buah-Buahan Menurut Negara Tujuan Menggunakan K-Means Clustering,”vol. 16, no. 4, pp. 348-357, 2017. 